\title{
Incentivizing sustainable development: The impact of a recent policy reform on electricity production efficiency in China
}

\author{
Fan $\mathrm{Li}^{1}$ (D) | Jiajia Xie ${ }^{2}$ | Wenche Wang ${ }^{3}$ (D)
}

\author{
${ }^{1}$ China Center for Special Economic Zone \\ Research, Shenzhen University, Shenzhen, \\ Guangdong, China \\ ${ }^{2}$ Department of Finance, College of \\ Economics, Shenzhen University, Shenzhen, \\ Guangdong, China \\ ${ }^{3}$ Sport Management, School of Kinesiology, \\ University of Michigan, Ann Arbor, Michigan \\ Correspondence \\ Wenche Wang, Sport Management, School of \\ Kinesiology, University of Michigan, 1402 \\ Washington Heights, Ann Arbor, MI 48109. \\ Email:wwenche@umich.edu
}

\begin{abstract}
China's rapid economic growth has tremendously accelerated its energy use, calling for a more sustainable supply of scarce and nonrenewable energy. Using a firmlevel dataset of 30 major Chinese electricity utilities from 2010 to 2014, this paper applies a stochastic frontier analysis to determine the utilities' technical efficiency, incorporating their operational environments related to a recent policy reform to encourage sustainable development. Our main findings are (a) state ownership, consumer density, and a chief executive officer with a science and engineering background are factors that can improve technical efficiency; (b) asset-related subsidy increases efficiency whereas income-related subsidy lowers efficiency; and (c) the five largest regional electricity generation firms exhibit above-average efficiency levels. These results provide evidence that supports the recent Chinese policy reform. The findings also suggest that electricity generation efficiency, which is essential to sustainable economic development, can be improved through performance-based regulation and incentives.
\end{abstract}

\section{KEYWORDS}

efficiency, electricity, government subsidy, stochastic frontier analysis

\section{1 | INTRODUCTION}

The world has witnessed China's rapid economic growth in the past decades and its continued growth in recent years. According to the National Bureau of Statistics of China, China's gross domestic product has increased from 41,303.03 billion RMB in 2010 to 64,397.40 billion RMB in 2014. This economic growth has tremendously accelerated its energy demand, calling for a more effective and sustainable use of scarce and nonrenewable energy (Lin \& Jiang, 2011). In 2014, China's total consumption of standard coal topped the world at 4.26 billion tons. China burns more coal (accounting for more than $50 \%$ of global consumption) and emits more carbon and sulfur dioxide due to electricity generation than any other country (Boden, Marland, \& Andres, 2010; Smith et al., 2011; BP, 2013).

Meanwhile, China is facing substantial risk of a shortage in electricity supply that may lead to considerable economic cost and hinder sustainable economic growth (Ou, Huang, \& Yao, 2016). Policymakers are urged to take serious actions to ensure electricity supply. Improving efficiency on the supply side is an essential step toward sustainable economic development (Ma, Shi, \& Chou, 2016). Thus, along with encouraging the development of renewable energy sources, the Chinese government has been working to introduce competition on the supply side and encourage energy savings on the demand side and incentivizing electricity utilities to advance their technologies (Ma \& Zhao, 2015). With the goal to encourage utilities to invest in research and development as well as equipment upgrades, the recent policy reform in China has two distinct features. First, rather than assisting in the development of all electricity generation utilities, the Chinese government places emphasis on large utilities. Second, the government specifically defined two types of subsidies based on where the subsidy will be used: asset investment or income compensation (Wang \& Lin, 2017).

In this paper, we apply a stochastic frontier analysis (SFA) to examine the performance of the Chinese electricity generation utilities, 
controlling for the operational environments that reflect the current policy. The SFA model allows us to examine a firm's efficiency by including a noise $\left(v_{i t}\right)$ and production inefficiency $\left(u_{i t}\right)$ as error terms. Efficiency is defined as the firm's actual output relative to the output that could have been produced with the same input vector had the firm been fully efficient. Operational environments related to the current policy are incorporated to explore the effect of the policy reform on electricity generation.

Government subsidies crucially affect the performance of public utility sectors such as electricity, natural gas, and water. Firms can use the subsidies to replace aging equipment which will improve the firms' production efficiency. Firms can also use the subsidies to compensate for heavy labor and production costs which will necessarily reduce both their budget and incentives to improve efficiency. Previous research has focused on examining the overall impact of government subsidies on firms' production efficiency. Due to the contradicting effects of the two subsidies, the impacts of the subsidies may offset each other, leading to an underestimation of the influence of each individual subsidy. Even though the literature has recognized the existence of heterogeneity in subsidies and their corresponding opposing impact, to our best knowledge, there has yet to be any empirical work that explicitly investigates the differential effects of government subsidies on firms' performance.

The recent Chinese policy reform on government subsidies provides us an opportunity to directly analyze the two contradicting effects of government subsidies. The current Chinese policy reform makes a clear distinction between asset-related subsidy and incomerelated subsidy: The former can only be spent on equipment, plant, and property whereas the latter can be spent on anything other than long-term assets. The government can easily monitor and track the use of asset-related subsidies but may not be able to do so for income-related subsidies. Under strict supervision, electricity utilities must spend the asset-related subsidies on plants, equipment, and network upgrades, which will lead to better operational performance and will improve the firm's technical efficiency. Without serious monitoring, electricity utilities may use the income-related subsidies to compensate for their loss, which will reduce their incentives to lower costs and improve production efficiency.

Using this unique feature in the reform policy, we find that although asset-related subsidy improves efficiency, income-related subsidy may pose an adverse effect on efficiency. By distinguishing the impacts from the two government subsidies, our paper contributes to the literature by providing sound empirical evidence that confirm the underlying mechanism of government subsidies predicted in the theory. Our findings also draw important implications to the optimal subsidy design. Simply distributing subsidies to electricity utilities is unlikely to achieve a long-term goal of technology advancement. Instead, the government and regulators may consider issuing specific guidelines on how the subsidies will be used. Additionally, certain policies may be necessary to enhance the transparency in the use of subsidy by the utilities. Only when the subsidy is spent on replace aging equipment, research and development and other forms of technology advancement will there be long-term improvement in production efficiency.
The rest of the paper is organized as follows. Section 2 reviews the market structure of the electricity generation sector in China and summarizes the recent policy reform of sustainable development in the Chinese electricity sector. Section 3 provides a review of the literature on the efficiency of electricity generation. Section 4 introduces the SFA model, and Section 5 presents the estimation results. Section 6 concludes the paper and draws policy implications on efficiency improvement and sustainable development.

\section{2 | ELECTRICITY GENERATION REFORM IN CHINA}

In China, the National Energy Administration founded in 2013 oversees the development and reforms of the entire energy sector. ${ }^{1}$ The Chinese electricity generation sector faces increasing problems of aging facilities, limited capacity, and low skill level of labor due to lack of education and professional training. Consequently, to ensure longterm electricity supply, there is a strong and urgent need for technology advancement in the energy generation sector.

The State Power Corporation held monopoly power in both electricity generation and electricity distribution sectors in China prior to 2002, at which time the State Council launched a restructuring program to dismantle the State Power Corporation into a number of regional electricity utilities (Lam \& Shiu, 2004; Zeng, Yang, Wang, \& Sun, 2016). This decentralization aimed to introduce competition in the electricity sector. The restructuring program, however, did not result in perfect competition. Since then, five regional electricity generation companies (Huaneng, Datang, Huadian, Guodian, and State Power Investment Corporation) grew and began to dominate the electricity generation market. Meanwhile, two power grid operators, the State Grid Corporation of China and the China Southern Power Grid, gradually became the dominant firms in the electricity distribution sector. Currently, there are six regional grids in China, of which five are managed by the State Grid Corporation of China (north, northeast, east, central, and northwest), and an independent grid (south) is managed by the China Southern Power Grid.

Ongoing reforms intend to improve efficiency by separating power plants from power supply grids and privatizing a significant number of state-owned properties. Most recently, during China's 11th five-year plan between 2006 and 2010, the government launched a new policy: Promote Large and Close Small (Zhang, Kong, Choi, \& Zhou, 2014). This policy aims to shut down all the remaining small regional electricity utilities and encourage the development of the five largest electricity generation firms. It is believed that economies of scale can improve generation efficiency while strengthening competition among the five utilities.

Although competition was introduced to the electricity generation sector, the Chinese government maintains some control. Government intervention and price regulation suppress the price of electricity to below the cost of operation. To maintain the operation of the utility

${ }^{1} \mathrm{~A}$ detailed description of the functions of the NEA is available on the National Development and Reform Commission (NDRC)'s website at ndrc.gov.cn. 
plants and ensure electricity supply, the Chinese government must provide large subsidies to the electricity generation utilities. On February 15, 2006, the Ministry of Finance issued the No. 16 Accounting Standards for Enterprises which became effective on January 1, 2007. This document defines two types of government subsidies: asset-related subsidy and income-related subsidy. The former can be used by a qualified electricity utility to purchase, acquire, or construct long-term assets, such as equipment and plants; the latter can be used for almost any other expense. Both types of subsidies must be published in the recipient's financial report. With this new standard, the Chinese government not only determines the amount of subsidy distributed to the electricity utilities but also imposes restrictions on how the subsidy can be used.

\section{I LITERATURE REVIEW}

There has been extensive research on electricity utility efficiency. Recent studies have highlighted the importance of incorporating operational environments that may affect utilities' performance (Sueyoshi \& Goto, 2011; Sueyoshi, Goto, \& Ueno, 2010; Yang \& Pollitt, 2009, 2010). Most of these studies employ either a data envelopment analysis (DEA) or a SFA. DEA, a nonparametric method, applies linear programming to determine the efficiency of firms without assuming a functional form of the production function. The standard DEA does not consider operational or environmental factors when determining efficiency. Though other advanced methods can be added to a standard DEA to incorporate these factors, it may also introduce noise to the model. SFA, a parametric method, applies statistical analysis to examine efficiency while controlling for environmental factors. However, SFA assumes functional forms for the production function and the cost function. There are advantages and disadvantages for both DEA and SFA, and neither method is strictly preferred over the other. $^{2}$

Table 1 presents a summary of the studies on energy generation efficiency in China. The amount of electric power generated is generally used as the output variable whereas capital, labor, and fuel consumption are used as input variables (Bi, Song, Zhou, \& Liang, 2014; Fallahi, Ebrahimi, \& Ghaderi, 2011; Lam \& Shiu, 2001, 2004; Ma \& Zhao, 2015; Yang \& Pollitt, 2009, 2010; Zhang et al., 2014; Zhang \& Choi, 2013; Zhao \& Ma, 2013; Zhou, Xing, Fang, Liang, \& Xu, 2013). Some studies also include the utility's installed capacity as an input (Bi et al., 2014; Fallahi et al., 2011; Ma \& Zhao, 2015; Yang \& Pollitt, 2009, 2010). Additionally, some papers use undesirable output, such as the emissions of $\mathrm{SO}_{2}, \mathrm{NO}_{x}$, and $\mathrm{CO}_{2}$, as output variables to address the issue of pollution (Bi et al., 2014; Yang \& Pollitt, 2009, 2010; Zhang \& Choi, 2013; Zhou et al., 2013).

Most studies conduct a standard DEA to analyze firms' efficiency without incorporating environmental factors (Bi et al., 2014; Fallahi et al., 2011; Zhang \& Choi, 2013). Some works apply more advanced regression methods to a standard DEA to account for environmental factors (Lam \& Shiu, 2001, 2004; Zhao \& Ma, 2013; Zhou et al.,

${ }^{2}$ See Coelli et al. (2005) for a detailed comparison of DEA and SFA.
2013). There are also studies that apply an SFA to incorporate operational environments such as innovation capability, ownership, plant size, location, and foreign direct investment to estimate efficiency (Chen, Barros, \& Borges, 2015; Ma \& Zhao, 2015). Because the focus of our paper is to examine the impact of the recent policy reform on the efficiency of electricity generation in China which is reflected in the environmental factors, we believe that SFA is the most appropriate method to evaluate firms' performance due to its ability to take into account environmental factors.

Existing research has explored the overall impact of government subsidies on electricity production using aggregate measures of government subsidies. They have found mixed results. Some studies find a positive impact of government subsidy on electricity production as the subsidy provides financial support to the firms (Alavi, 1994; China Electricity Council, 2016; Jin, Shang, \& Xu, 2018; Nicolini \& Tavoni, 2017). Some studies find that government subsidy may decrease production efficiency because firms can use the subsidies to pay for the high cost of production rather than invest in research and development (Rezitis, Tsiboukas, \& Tsoukalas, 2003; Phillips, 2013; Dhital et al., 2016). There are also studies that find a more complicated relationship between government subsidy and utilities' technical efficiency. Marques, Berg, and Yane (2014) finds that the impact of government subsidy on the efficiency of water utilities in Japan depends on the ratio between subsidy and total operating expense. Yu, Guo, Le-Nguyen, Barnes, and Zhang (2016) also suggest that the influence of government subsidy on the R\&D incentives in the Chinese renewable energy sector may change as the size of the subsidy changes.

Government subsidy to public utilities may be spent in different ways. Where and how the money is spent may affect the utilities' long-term production efficiency. In the existing literature, to the best of our knowledge, only two papers (Andor \& Voss, 2016; Reichenbach $\&$ Requate, 2012) recognize the potentially different effects of government subsidies and discuss the implications of distinguishing subsidies. They examine theoretically the impact of capacity subsidy and generation subsidy on the externalities in the electricity markets. We have yet to find any studies that analyze the impact of government subsidies on utilities' production efficiency by distinguishing the subsidies by their types or usages. The current Chinese policy explicitly defines subsidy by its usage which allows us to empirically explore the underlying relationship between the two types of government subsidies (asset-related subsidy and income-related subsidy) and firms' technical efficiency.

Moreover, due to data limitation, there are very few studies on the efficiency of electricity generation in China using firm-level data. Wind, a financial information service company, collects firm-level operation and financial data of 21 major industries in China from the National Bureau of Statistics, the National Development and Reform Commission, the Ministry of Commerce, the General Administration of Customs, and other industry associations. Its economic database contains recent financial and market information on China's capital market. With firm-level data, rather than city-level or province-level data that are commonly used in existing studies, this paper contributes 

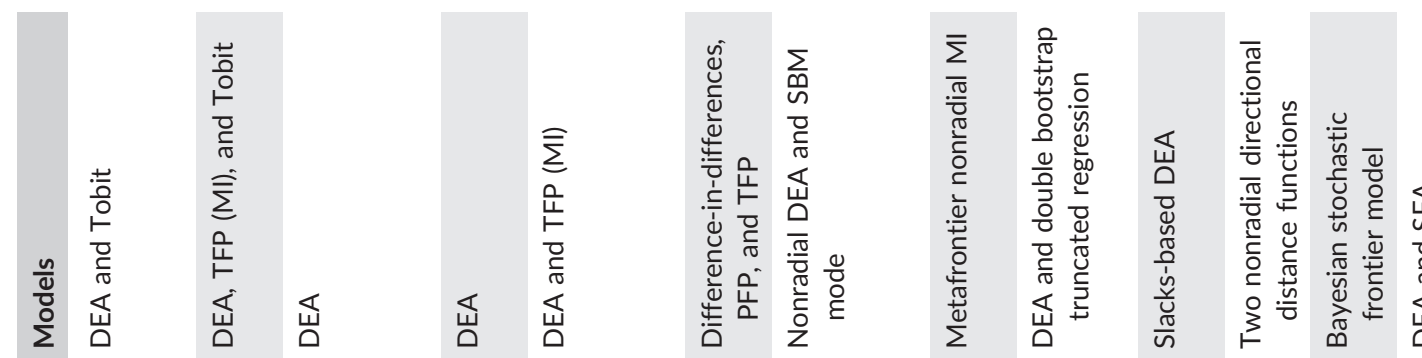

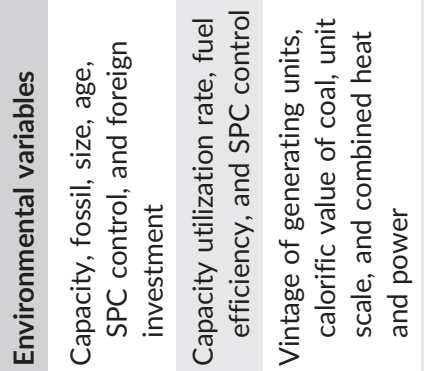
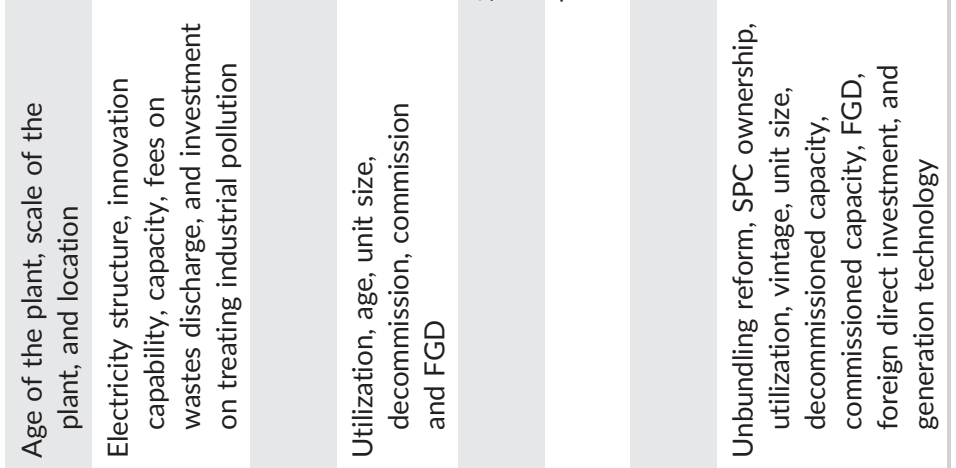

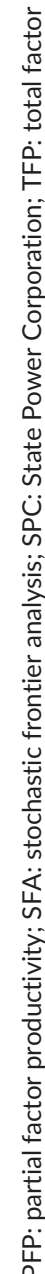

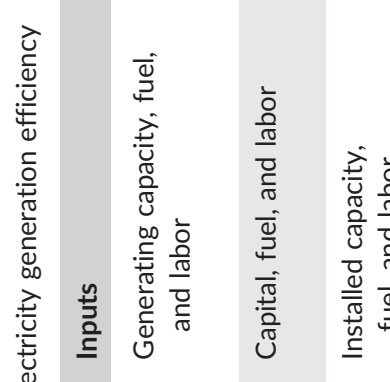
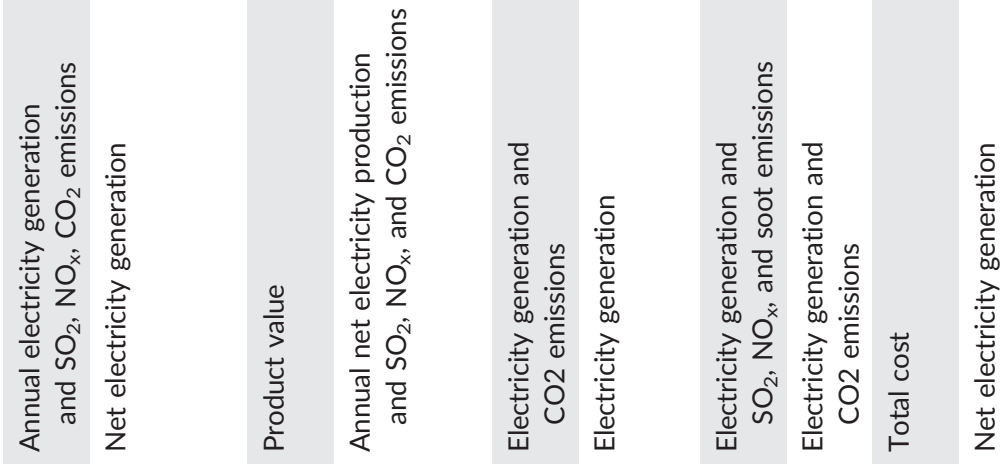

菊
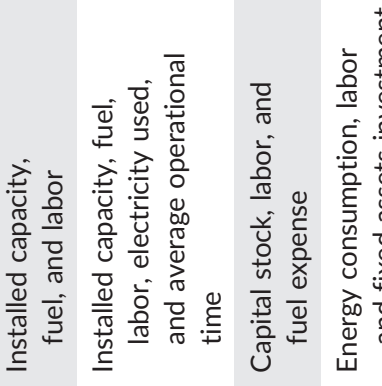

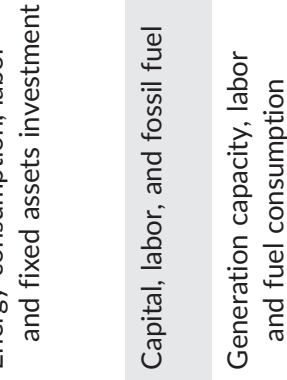

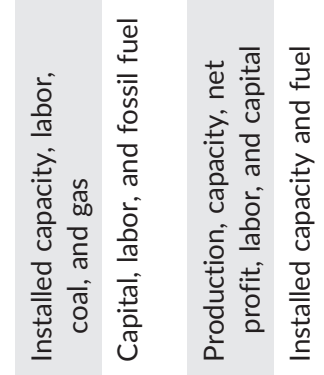

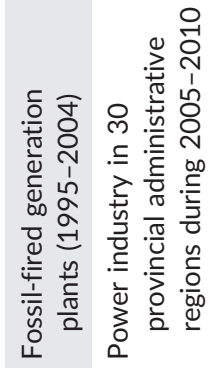

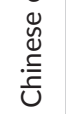

ป

를

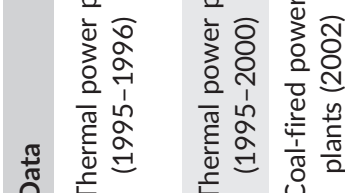

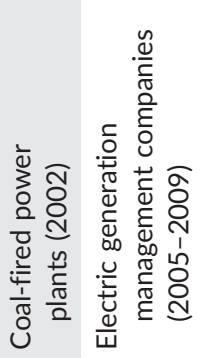

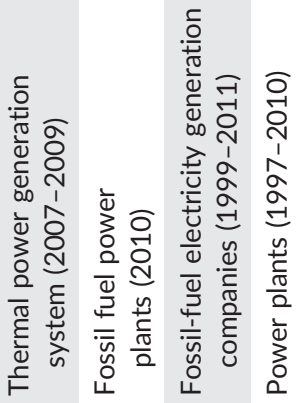

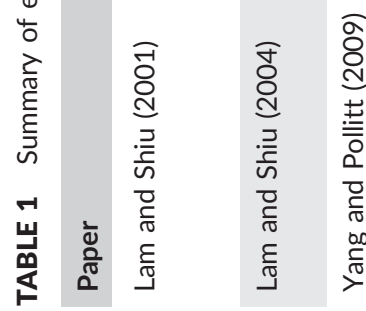

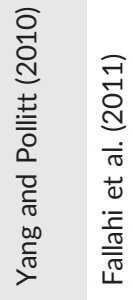

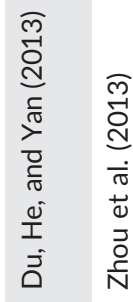

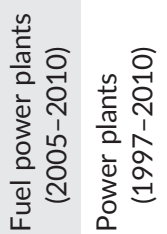

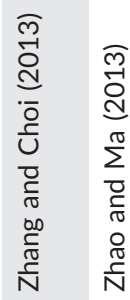

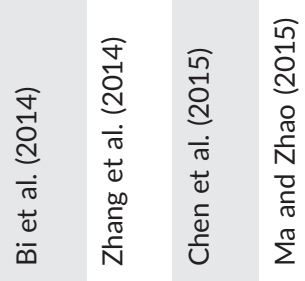

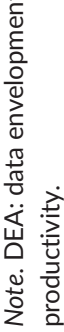


to the literature by providing more accurate estimates of the role of the different government subsidies on technical efficiency.

\section{4 | MODEL}

\section{1 | Data description}

The main source of data is the annual financial reports of individual electricity utilities available at the Wind-Economics Database. We use a pooled unbalanced panel sample consisting of 30 major electricity generation utilities (105 observations) between 2009 and 2013. ${ }^{3}$

\section{2 | Production function model description}

Our study applies an SFA to estimate the production efficiency of electricity utilities in China, incorporating operational and regulatory factors. The SFA incorporates both random noises $\left(v_{i t}\right)$ and the differences in systematic inefficiency $\left(u_{i t}\right)$ between samples which allows a comparison of the performances of the electricity utilities.

We use a one-step SFA model to measure inefficiency as proposed by Battese and Coelli (1995). The model was estimated using Frontier 4.1, a program written by Professor Tim Coelli. The Cobb-Douglas stochastic frontier production function is specified as follows:

$$
\ln Y_{i t}=\beta_{0}+\beta_{1} \ln \left(L_{i t}\right)+\beta_{2} \ln \left(F A_{i t}\right)+\beta_{3} \ln \left(I C_{i t}\right)+v_{i t}-u_{i t},
$$

where each firm is indexed with a subscript $i(i=1, \ldots, l)$ and each year is indexed with a subscript $t(t=1, \ldots, T) . Y_{i t}$ is the total amount of electric power generated by firm $i$ in year $t$ in million kilowatt hour. $L_{i t}$ denotes the number of staff, and $F A_{i t}$ is the total fixed asset reported in the annual balance sheet in million RMB. $I C_{i t}$ denotes the installed capacity which is defined as the maximum rated output of a generator, prime mover, or other electric power production equipment under specific conditions designated by the manufacturer in $10,000 \mathrm{kw} . v_{\text {it }}$ is an error term which is assumed to be independently and identically distributed with normal distribution $N\left(0, \sigma^{2}\right)$. The technical inefficiency term $u_{i t}$, consisting of nonnegative random variables, is subtracted because inefficiency lowers output. $u_{i t}$ is assumed to be independent of $v_{i t}$ and truncated at zero with normal distribution $N\left(Z_{i t}, \sigma^{2}\right)$, where $Z_{i t}$ is a vector of independent variables associated with production inefficiency of the electricity utilities over time. The list of independent variables and their descriptions are available in Table 2.

The relationship between $u_{i t}$ and $Z_{i t}$ is defined by the following technical inefficiency effects specification:

$$
\begin{aligned}
u_{i t} & =F\left(Z_{i t}\right) \\
& =\delta_{0}+\delta_{1}\left(\text { asubr }_{i t}\right)+\delta_{2}\left(\text { isubr }_{i t}\right)+\delta_{3}\left(\text { statown }_{i t}\right)+\delta_{4}\left(\text { cuscon }_{i t}\right) \\
& +\delta_{5}\left(\text { techCEO }_{i t}\right)+w_{i t},
\end{aligned}
$$

where $w_{i t}$ is an independently and identically distributed random vari-

\begin{tabular}{|c|c|c|}
\hline Variable & Description & Definition \\
\hline asubr & $\begin{array}{l}\text { Percentage of asset-related } \\
\text { subsidy }\end{array}$ & $\begin{array}{l}\text { Sum of asset-related } \\
\text { subsidies divided by the } \\
\text { total revenue of the utility } \\
\text { (\%) }\end{array}$ \\
\hline isubr & $\begin{array}{l}\text { Percentage of income-related } \\
\text { subsidy }\end{array}$ & $\begin{array}{l}\text { Sum of income-related } \\
\text { subsidies divided by the } \\
\text { total revenue of the utility } \\
\text { (\%) }\end{array}$ \\
\hline statown & $\begin{array}{l}\text { Percentage of state-owned } \\
\text { stock }\end{array}$ & $\begin{array}{l}\text { Ratio of state-owned stock to } \\
\text { the total stock (\%) }\end{array}$ \\
\hline cuscon & Consumer concentration & $\begin{array}{l}\text { Percentage of the total sales } \\
\text { revenue from the utility's } \\
\text { five largest consumers (\%) }\end{array}$ \\
\hline techCEO & $\begin{array}{l}\text { Education background of the } \\
\text { chief executive officer } \\
\text { (CEO) of the utility }\end{array}$ & $\begin{array}{l}\text { techCEO = } 1 \text { if the CEO } \\
\text { majored in science or } \\
\text { engineering; techCEO =0 } \\
\text { otherwise }\end{array}$ \\
\hline
\end{tabular}
able that follows a truncated normal distribution, $N\left(0, \sigma^{2}\right.$; Coelli,

\footnotetext{
${ }^{3}$ Our sample is an unbalanced panel due to the lack of information on some years.
}

TABLE 2 Environmental variables $Z_{i t}$

1996; Battese \& Coelli, 1995). Among the environmental variables $Z_{i t}$, the main explanatory variables are the percentage of asset-related subsidy $\left(a s u b r_{i t}\right)$ and the percentage of income-related subsidy (isubr $r_{i t}$ ). The control variables include the percentage of state-owned stock $\left(\right.$ statown $\left._{i t}\right)$, consumer concentration $\left(\right.$ cuscon $\left._{i t}\right)$, and the education background of the chief executive officers (CEOs) of the utility (techCEO ${ }_{i t}$ ).

Table 3 presents the summary statistics of the variables included in Equations 1 and 2.

This study applies the maximum likelihood estimation to estimate the parameters in the production function (Equation 1) and technical inefficiency effect (Equation 2) simultaneously.

Following Coelli, Rao, O'Donnell, and Battese (2005), technical efficiency of production for a utility $i$ in year $t$ is defined as follows:

\begin{tabular}{|c|c|c|c|c|}
\hline Variable & Mean & $\begin{array}{l}\text { Standard } \\
\text { deviation }\end{array}$ & Min & Max \\
\hline \multicolumn{5}{|l|}{ Production function } \\
\hline Electric power $(Y)$ & 564.85 & 703.43 & 4.24 & $3,174.81$ \\
\hline Number of staff $(L)$ & 8340.14 & 9065.31 & 491.00 & $37,737.00$ \\
\hline Fixed asset (FA) & 50552.95 & 64644.33 & 1011.83 & $249,607.84$ \\
\hline Installed capacity (IC) & 1231.45 & 1500.14 & 11.00 & $7,048.00$ \\
\hline \multicolumn{5}{|l|}{$\begin{array}{l}\text { Technical inefficiency } \\
\text { effect }\end{array}$} \\
\hline asubr & 0.07 & 0.10 & 0.00 & 0.55 \\
\hline isubr & 0.95 & 1.85 & 0.00 & 8.80 \\
\hline statown & 57.51 & 16.10 & 14.43 & 92.19 \\
\hline cuscon & 75.05 & 24.09 & 12.61 & 100.00 \\
\hline techCEO & 0.72 & 0.45 & 0 & 1 \\
\hline Observations & 105 & & & \\
\hline
\end{tabular}

$$
T E_{i t}=e^{-u_{i t}} .
$$

TABLE 3 Summary statistics 
That is, technical efficiency is defined as the utility's maximum production given a fixed level of inputs. This efficiency score is measured on a scale between 0 and 1 . A score closer to 1 is considered more efficient.

\section{5 | ESTIMATION RESULTS}

\section{1 | Ordinary least squares estimation}

In a stochastic frontier model, the error is given by $v_{i t}-u_{i t}$. If technical inefficiency $u_{i t}$ is not a part of the error term, ordinary least squares (OLS) will be sufficient to produce consistent estimates. An OLS estimation is performed as the benchmark analysis and the results are presented in Table 4.

The OLS benchmark analysis suggests that labor, fixed assets, and installed capacity are all positive factors that lead to higher production. Battese and Coelli (1995) proposed a gamma value $\gamma=\frac{\sigma_{u}{ }^{2}}{\sigma^{2}}$ to test the consistency of OLS estimates. The null hypothesis is that $\gamma=0$, that is, technical inefficiency is not present in the error term. Our estimated $\gamma$ is 0.44 , and it is statistically different from zero with a t-statistics of 1.75; thus, at least some variation of the error term is due to inefficiency. Because OLS will not produce consistent estimates, we turn our attention to SFA estimation.

\section{2 | SFA estimation}

The main estimation results using an SFA are shown in Table 5. The estimated coefficients of the control variables have the expected positive signs and are statistically significant at conventional levels. For instance, a $1 \%$ increase in the number of staff leads to about $0.22 \%$ increase in the electricity output whereas a $1 \%$ increase in installed

TABLE 4 Ordinary least squares estimation results of production function

\begin{tabular}{|lc|}
\hline Variable & Estimated coefficient \\
\hline Intercept $\left(\beta_{0}\right)$ & $-2.34^{* * *}$ \\
\hline Log (number of staff) & $(-4.99)$ \\
\hline Log (fixed assets) & 0.04 \\
\hline Log (installed capacity) & $(0.68)$ \\
\hline$R^{2}$ & $0.22^{* *}$ \\
\hline Observations & $(2.31)$ \\
\hline
\end{tabular}

Note. t-statistics are provided in parentheses.

*Statistical significance at the $10 \%$ level.

${ }^{* *}$ Statistical significance at the $5 \%$ level.

${ }^{* * *}$ Statistical significance at the $1 \%$ level.
TABLE 5 Stochastic frontier analysis estimation results of production function and technical inefficiency

\begin{tabular}{|c|c|}
\hline Variable & Estimated coefficient \\
\hline \multicolumn{2}{|l|}{ Production function } \\
\hline \multirow[t]{2}{*}{ Intercept $\left(\beta_{0}\right)$} & $-2.86^{* * *}$ \\
\hline & $(-6.14)$ \\
\hline \multirow[t]{2}{*}{ Log (number of staff) } & $0.22^{* * *}$ \\
\hline & $(4.22)$ \\
\hline \multirow[t]{2}{*}{ Log (fixed assets) } & $0.55^{* * *}$ \\
\hline & $(5.14)$ \\
\hline \multirow[t]{2}{*}{ Log (installed capacity) } & $0.23^{*}$ \\
\hline & (1.91) \\
\hline \multicolumn{2}{|l|}{ Technical Inefficiency } \\
\hline \multirow[t]{2}{*}{ Intercept $\left(\delta_{0}\right)$} & $3.83^{* * *}$ \\
\hline & (8.57) \\
\hline \multirow[t]{2}{*}{ asubr } & $-2.54^{* * *}$ \\
\hline & $(-3.53)$ \\
\hline \multirow[t]{2}{*}{ isubr } & $0.16^{* * *}$ \\
\hline & (3.89) \\
\hline \multirow[t]{2}{*}{ statown } & $-0.03^{* * *}$ \\
\hline & $(-4.66)$ \\
\hline \multirow[t]{2}{*}{ cuscon } & $-0.03^{* * *}$ \\
\hline & $(-6.59)$ \\
\hline \multirow[t]{2}{*}{ techCEO } & $-0.27^{*}$ \\
\hline & $(-1.70)$ \\
\hline Observations & 105 \\
\hline
\end{tabular}

Note. $\mathrm{t}$-statistics are provided in parentheses. Cross section $=30$.

*Statistical significance at the $10 \%$ level.

${ }^{* *}$ Statistical significance at the $5 \%$ level.

${ }^{* * *}$ Statistical significance at the $1 \%$ level.

capacity increases the total electricity output by about $0.23 \%$. Moreover, state ownership, consumer concentration, and the CEO's engineering education all reduce technical inefficiency and increase technical efficiency.

We find that asset-related subsidy lowers technical inefficiency (i.e., improves efficiency), but income-related subsidy increases technical inefficiency (i.e., decreases efficiency), and income-related subsidies can be used to compensate for the utilities' loss and can be deducted from their expense reports. Our estimated results provide empirical evidence that support the theoretical predictions. Because asset-related subsidies can only be used to acquire or construct long-term assets and especially under government supervision and monitoring, the electricity utilities would have to spend this money on plants, equipment, and network upgrades. Their operational performance, therefore, will improve. ${ }^{4}$ On the other hand, there is no strict

${ }^{4}$ Larger plants and newer equipment have been found to improve production efficiency. For example, Zhang et al. (2014) find that larger plant size leads to higher fossil fuel generation efficiency. 
restriction on where the income-related subsidy can be spent. Utilities can therefore use this money to compensate for their loss and deduct them from their expense reports. This not only takes away the financial opportunity for the utilities to advance technology but also reduces their incentive to do so.

Moreover, the estimated coefficient on the percentage of stateowned share (statown) is negative and statistically significant at the $1 \%$ level, implying that electricity generation utilities with a higher percentage of state-owned capital perform more efficiently. This result contradicts with Sarıca and Or (2007). They find that the performance efficiency of the state-owned thermal plants is significantly lower than their private counterparts in the Turkish power generation industry due to the higher operational costs of the state-owned plants. In China, however, due to the extremely large demand for electricity, electricity utilities rely heavily on investment on fixed assets, network maintenance, and management training. With government funding on professional staff, advanced administration, and more advanced techniques, firms with a larger state share will have an operational advantage. In fact, the top five power generation firms, Huaneng, Datang, Huadian, Guodian, and State Power Investment Corporation, are almost entirely state owned. Their operation performances are better than those that are mainly owned by private parties. The estimated coefficient on consumer concentration is negative and statistically significant. The electricity utilities with higher consumer density have a lower inefficiency level. This finding is consistent with Farsi and Filippini (2009), which suggest that higher consumer density can lower production costs. We also test the importance of the education background of a firm's CEO. In the Chinese electricity sector, most CEOs have a science, engineering, economics, or political science degree. Our result suggests that a CEO with a science or engineering background can improve the utility's technical efficiency. This is likely because those with a background in science or engineering pay more attention to research and development, reconstruction of plants, and replacement of aging equipment whereas those with social science backgrounds may focus on business strategies and administration. Although traditionally those with business or social science backgrounds are better suited for the role of CEOs, in the current structure of the electricity sector in China that relies heavily on technological advancement, scientists and engineers may be better leaders for the electricity utilities.

This study further explores the distribution of the estimated efficiency scores of the electricity utilities and calculates the percentage of total electric power generated based on the utility's efficiency score. Figure 1 includes both the frequency of utilities with different ranges of efficiency scores and the percentage of electricity generated by utilities with the associated efficiency scores. Our estimated efficiency score ranges from 0.08 (least efficient) to 0.98 (most efficient), suggesting a large gap in the production efficiency among the electricity utilities. Additionally, the least efficient utility could reduce input usage by an astonishing $92 \%$. The efficiency score is averaged at 0.70 which means that about $30 \%$ of the costs can be reduced without decreasing output should the utility achieve perfect efficiency. About $61 \%$ of the utilities have an efficiency score above 0.70 , generating $77.23 \%$ of the total electric power. Thus, most electricity in China is generated by utilities with an above-average efficiency level.

Table 6 summarizes the output and estimated efficiency score by year, and Table 7 presents the summary statistics of firm-level installed capacity. The highest average output appears in 2012 at 60.91 billion kWh. This is likely due to the change in installed capacity (see Table 7). Except from 2010 to 2011, the growth of installed capacity affects the growth of predicted output positively which is consistent with the finding in the Chinese Electricity Sector Report from the China Electricity Council (2016). They show a strong correlation between installed capacity and the output level of electricity generation.

In Table 8, we compare the input factors, output factor, and efficiency scores between the top five electricity generation utilities and the rest of the utilities. The top five utilities are better equipped with labor, fixed assets, and installed capacity. Though the mean efficiency score of the top five utilities is statistically significantly higher than that of the rest utilities with a t-statistics of 1.69 , the size of this difference is not substantial. Although this finding does confirm that the Chinese government is providing more political and financial support to large utilities, it also suggests that more incentives need to be provided for the top five utilities to further improve their production efficiency.

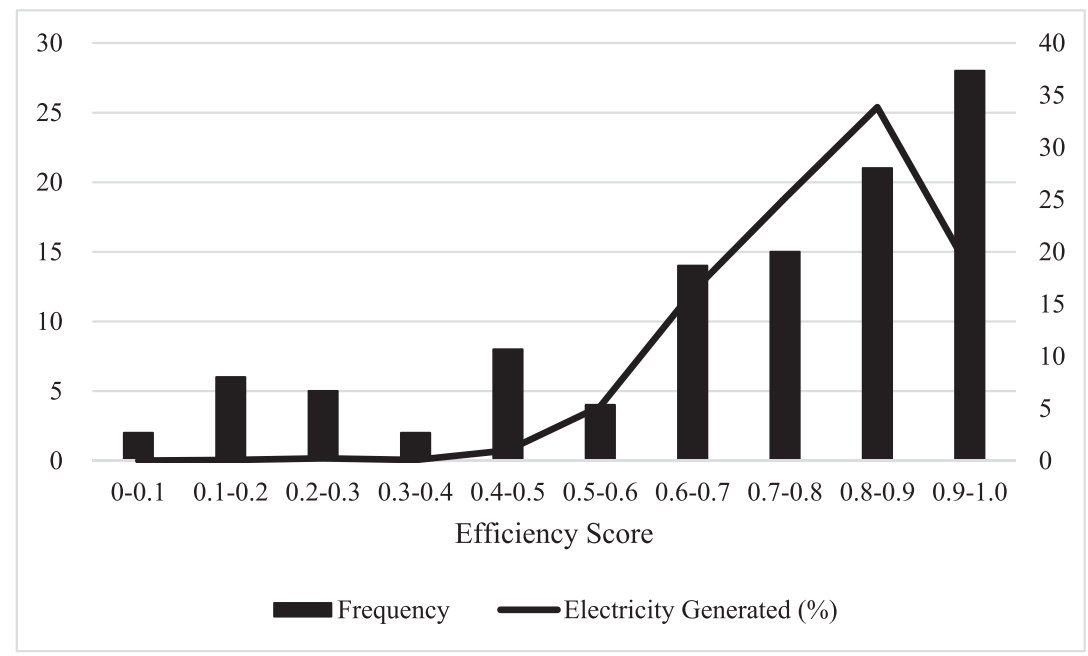

FIGURE 1 Distribution of efficiency scores and outputs 
TABLE 6 Predicted output and efficiency scores

\begin{tabular}{|c|c|c|c|c|}
\hline Variable & Mean & Standard deviation & Min & Max \\
\hline \multicolumn{5}{|l|}{2010} \\
\hline Output & 504.34 & 552.37 & 32.05 & $1,784.78$ \\
\hline Efficiency score & 0.76 & 0.17 & 0.38 & 0.97 \\
\hline \multicolumn{5}{|l|}{2011} \\
\hline Output & 514.12 & 592.32 & 9.29 & $2,037.16$ \\
\hline Efficiency score & 0.74 & 0.21 & 0.19 & 0.96 \\
\hline \multicolumn{5}{|l|}{2012} \\
\hline Output & 609.13 & 788.06 & 5.14 & $3,024.33$ \\
\hline Efficiency score & 0.7 & 0.27 & 0.08 & 0.96 \\
\hline \multicolumn{5}{|l|}{2013} \\
\hline Output & 576.69 & 758.51 & 4.24 & $3,174.81$ \\
\hline Efficiency score & 0.69 & 0.28 & 0.08 & 0.97 \\
\hline \multicolumn{5}{|l|}{2014} \\
\hline Output & 589.76 & 776.69 & 4.37 & $2,943.88$ \\
\hline Efficiency score & 0.66 & 0.27 & 0.15 & 0.98 \\
\hline \multicolumn{5}{|l|}{ 2010-2014 } \\
\hline Output & 564.85 & 703.43 & 4.24 & $3,174.81$ \\
\hline Efficiency score & 0.7 & 0.25 & 0.08 & 0.98 \\
\hline
\end{tabular}

TABLE 7 Output and installed capacity

\begin{tabular}{llllll} 
Year & Output & & & \multicolumn{2}{l}{ Installed capacity } \\
\cline { 2 - 3 } \cline { 5 - 6 } & Total & Growth rate (\%) & & Total & Growth rate (\%) \\
\hline 2010 & 504.3 & - & 1113.64 & - \\
\hline 2011 & 514.1 & 1.94 & 1066.09 & -4.27 \\
\hline 2012 & 609.1 & 18.48 & 1295.84 & 21.55 \\
\hline 2013 & 576.7 & -5.33 & 1259.43 & -2.81 \\
\hline 2014 & 589.8 & 2.27 & 1342.39 & 6.59 \\
\hline
\end{tabular}

TABLE 8 Comparison between top five and the other utilities

\begin{tabular}{lrr} 
& Top five utilities & Other utilities \\
Inputs & & \\
Labor & $14,404.23$ & $4,134.40$ \\
Fixed asset & $76,852.62$ & $32,312.85$ \\
$\quad$ Installed capacity & $1,934.09$ & 744.14 \\
Output & & \\
Electricity generation & 908.12 & 326.77 \\
Efficiency score & 0.75 & 0.67 \\
\hline
\end{tabular}

Note. This table reports the means of the variables.

\section{3 | Robustness check: Alternative SFA estimations}

Technical efficiency levels may change systematically over time. Given that we have panel data, we can incorporate this potential dynamic feature of efficiency. In this subsection, we consider two alternative models that incorporate a time effect.

We first consider a time-varying inefficiency SFA proposed by Battese and Coelli (1992). The technical inefficiency term $u_{i t}^{\prime}$ is assumed to be

$$
u_{i t}^{\prime}=u_{i} e^{\eta(t-T)}
$$

where $u_{i}$ are random variables which have truncated normal distribution, $t$ indicates the current year of observation, $T$ is the entire sample period, and $\eta$ is a time-related parameter.

In this specification, the null hypothesis is that $\eta=0$, that is, technical inefficiency is independent of time after controlling. Thus, the estimated value of $\eta$ is used to determine whether we should apply a time-invariant or a time-varying efficiency model.

We estimate this time-varying efficiency model using the same independent variables in Equations 1 and 2. The estimated results are presented in Table 9. The estimated value of $\eta$ is -0.0033 , and it is not statistically different from zero with a t-statistics equal to -0.2948 . Therefore, we fail to reject the null hypothesis that technical inefficiency is independent of time. In other words, we do not have sound evidence that the technical efficiency of the utilities is changing over time.

We further consider adding year dummies to Equation 2 to control for unobserved time effect. Table 10 presents the estimation results with year dummies. None of the estimated coefficients on the year dummies is statistically significant. The coefficients on the input variables and the environmental variables remain similar to those in Table 5.

TABLE 9 Stochastic frontier analysis estimation results of production function with time-varying efficiency

\section{Variable}

Estimated coefficient

\section{Production function}

Intercept $\left(\beta_{0}\right)$

$-0.85$

\begin{tabular}{|c|c|}
\hline Log (number of staff) & $(-1.30)$ \\
& 0.00 \\
\hline Log (fixed assets) & $(0.05)$ \\
& $0.37^{* * *}$ \\
\hline Log (installed capacity) & $(4.31)$ \\
& $0.58^{* * *}$ \\
\hline Testing time-varying efficiency & $(5.79)$ \\
eta $(\eta)$ & -0.00 \\
\hline
\end{tabular}

Observations 105

Note. $\mathrm{t}$-statistics are provided in parentheses. Cross section $=30$.

*Statistical significance at the $10 \%$ level.

**Statistical significance at the $5 \%$ level.

${ }^{* * *}$ Statistical significance at the $1 \%$ level. 
TABLE 10 Stochastic frontier analysis estimation results of production function and technical inefficiency with year dummies

\begin{tabular}{|c|c|}
\hline Variable & Estimated coefficient \\
\hline \multicolumn{2}{|l|}{ Production function } \\
\hline \multirow[t]{2}{*}{ Intercept $\left(\beta_{0}\right)$} & $-2.76^{* * *}$ \\
\hline & $(-5.66)$ \\
\hline \multirow[t]{2}{*}{ Log (number of staff) } & $0.20^{* * *}$ \\
\hline & $(3.46)$ \\
\hline \multirow[t]{2}{*}{ Log (fixed assets) } & $0.55^{* * *}$ \\
\hline & (5.19) \\
\hline \multirow[t]{2}{*}{ Log (installed capacity) } & $0.24^{* *}$ \\
\hline & (1.99) \\
\hline \multicolumn{2}{|l|}{ Technical inefficiency } \\
\hline \multirow[t]{2}{*}{ Intercept $\left(\delta_{0}\right)$} & $3.80^{* * *}$ \\
\hline & (7.31) \\
\hline \multirow[t]{2}{*}{ asubr } & $-2.69^{* * *}$ \\
\hline & $(-3.31)$ \\
\hline \multirow[t]{2}{*}{ isubr } & $0.16^{* * *}$ \\
\hline & $(3.53)$ \\
\hline \multirow[t]{2}{*}{ statown } & $-0.03^{* * *}$ \\
\hline & $(-4.31)$ \\
\hline \multirow[t]{2}{*}{ cuscon } & $-0.03^{* * *}$ \\
\hline & $(-5.96)$ \\
\hline \multirow[t]{2}{*}{ techCEO } & $-0.29^{*}$ \\
\hline & $(-1.78)$ \\
\hline \multirow[t]{2}{*}{ Year $=2009$} & 0.21 \\
\hline & $(0.84)$ \\
\hline \multirow[t]{2}{*}{ Year $=2010$} & 0.16 \\
\hline & $(0.77)$ \\
\hline \multirow[t]{2}{*}{ Year $=2011$} & -0.01 \\
\hline & $(-0.05)$ \\
\hline \multirow[t]{2}{*}{ Year $=2012$} & 0.02 \\
\hline & $(0.09)$ \\
\hline Observations & 105 \\
\hline
\end{tabular}

Note. $\mathrm{t}$-statistics are provided in parentheses. Cross section $=30$.

${ }^{*}$ Statistical significance at the $10 \%$ level.

${ }^{* *}$ Statistical significance at the $5 \%$ level.

${ }^{* * *}$ Statistical significance at the $1 \%$ level.

The two exercises presented above suggest that the technical efficiency of the utilities is not systematically changing over time. They also confirm the robustness of our main results.

\section{6 | CONCLUSION}

Sustainable electricity generation is a cornerstone for economic development in China. Electricity generation can only be sustained if efficiency is improved. In this study, using a unique firm-level dataset from 2010 to 2014 , we examine the electricity utilities' production efficiency accounting for their operational environment under the recent policy reform. Our results suggest that there is a large disparity among the Chinese electricity utilities in production efficiency, ranging from an efficiency score of 0.08 to an efficiency score of 0.98. Efficiency can be substantially improved to ensure sustainable development if an appropriate regulatory framework that incorporates performance benchmarking into incentives is provided.

Our results confirm that more staffing, larger fixed assets, and increased installed capacity can all raise output levels. Therefore, better institutional control in the form of increasing installed capacities as well as the number of staffs and fixed assets should be imposed. In addition, we find that environmental factors, including the percentage of state-owned assets, consumer density, and a science and engineering education of a firm's CEO are crucial factors that can lead to higher technical efficiency. More importantly, our results suggest that government subsidy can improve efficiency only if the subsidy is used to replace aging equipment to advance technology. Subsidy may indeed reduce efficiency if it increases the utility's dependence on government's financial support.

The Chinese government promotes larger utilities and plans to shut down smaller ones. We show that the largest five regional power generation companies, Huaneng, Datang, Huadian, Guodian, and State Power Investment Corporation, do exhibit a higher level of technical efficiency. Unfortunately, compared with their significant advantage in labor, fixed asset, and installed capacity, their lead in efficiency appears to be negligible. Other than input investment, technical efficiency advancement is more urgent as it leads to improvement in the performance in operation and administration of utilities.

China has achieved great success in economic development; however, the increasing risks in the scarcity in electricity could hinder sustainable development. The issue of electricity supply has led to several recent policy reforms and is expected to continue to be the center of policy considerations. From a research perspective, this study explores China's electricity generation sector by depicting a clear, albeit preliminary, picture of the performance of electricity utilities and provides important policy implications. This study aims to raise the policymakers' awareness of possible changes in operational and institutional environments that can eventually lead to greater efficiency and more sustainable supply. A more comprehensive dataset with performance-based incentives could help identify other areas of improvement.

\section{ACKNOWLEDGEMENTS}

We are very grateful for the financial support from the National Natural Science Foundation of China (No: 71702109), the National Social Science Fund of China (No: 18ZDA004), the Natural Science Foundation of Guangdong Province, China (No: 2017A030310566), and the Scientific Research Foundation for Returned Overseas Chinese Scholars, State Education Ministry. Also, the Research Foundation of China Center for Special Economic Zone Research, Shenzhen University (No: CCSER1810) is also gratefully acknowledged. We are also very thankful for valuable suggestions provided by Michelle Phillips. 


\section{ORCID}

Fan Li (i) https://orcid.org/0000-0002-7238-4520

Wenche Wang (iD https://orcid.org/0000-0003-0320-1476

\section{REFERENCES}

Alavi, H. (1994). The control of industrial pollution: Implications for technology choice and growth. Sustainable Development, 2(2), 29-35. https://doi.org/10.1002/sd.3460020204

Andor, M., \& Voss, A. (2016). Optimal renewable-energy promotion: Capacity subsidies vs. generation subsidies. Resource and Energy Economics, 45, 144-158. https://doi.org/10.1016/j.reseneeco.2016. 06.002

Battese, G. E., \& Coelli, T. J. (1992). Frontier production functions, technical efficiency and panel data: With application to paddy farmers in India. Journal of Productivity Analysis, 3(1-2), 153-169. https://doi. org/10.1007/BF00158774

Battese, G. E., \& Coelli, T. J. (1995). A model for technical inefficiency effects in a stochastic frontier production function for panel data. Empirical Economics, 20, 325-332. https://doi.org/10.1007/BF012 05442

Bi, G. B., Song, W., Zhou, P., \& Liang, L. (2014). Does environmental regulation affect energy efficiency in China's thermal power generation? Empirical evidence from a slacks-based DEA model. Energy Policy, 66, 537-546. https://doi.org/10.1016/j.enpol.2013.10.056

Boden, T. A., Marland, G., \& Andres, R. J. (2010). Global, regional, and national fossil-fuel $\mathrm{CO}_{2}$ emissions. Carbon Dioxide Information Analysis Center, Oak Ridge National Laboratory, U.S. Department of Energy, Oak Ridge, Tennessee, U.S.A.

BP. (2013). BP Statistical Review of World Energy.

Chen, Z., Barros, C. P., \& Borges, M. R. (2015). A Bayesian stochastic frontier analysis of Chinese fossil-fuel electricity generation companies. Energy Economics, 48, 136-144. https://doi.org/10.1016/j.eneco. 2014.12.020

China Electricity Council. (2016). Chinese electricity sector report. China Market Press, Beijing, China.

Coelli, T. J. (1996). A guide to FRONTIER version 4.1: A computer program for stochastic frontier production and cost function estimation. University of New England CEPA Working Paper No. 7/96.

Coelli, T. J., Rao, D. S. P., O'Donnell, C. J., \& Battese, G. E. (2005). An introduction to efficiency and productivity analysis. New York, NY: Springer.

Dhital, R. P., Ito, Y., Kaneko, S., Komatsu, S., Mihara, R., \& Yoshida, Y. (2016). Does institutional failure undermine the physical design performance of solar water pumping systems in rural Nepal. Sustainability, 8(8), 770.

Du, L., He, Y., \& Yan, J. (2013). The effects of electricity reforms on productivity and efficiency of China's fossil-fired power plants: An empirical analysis. Energy Economics, 40, 804-812. https://doi.org/ 10.1016/j.eneco.2013.09.024

Fallahi, A., Ebrahimi, R., \& Ghaderi, S. F. (2011). Measuring efficiency and productivity change in power electric generation management companies by using data envelopment analysis: A case study. Energy, 36(11), 6398-6405. https://doi.org/10.1016/j.energy.2011.09.034

Farsi, M., \& Filippini, M. (2009). An analysis of cost efficiency in Swiss multi-utilities. Energy Economics, 31(2), 306-315. https://doi.org/ 10.1016/j.eneco.2008.11.009

Jin, Z., Shang, Y., \& Xu, J. (2018). The impact of government subsidies on private R\&D and firm performance: Does ownership matter in China's manufacturing industry? Sustainability, 10(7), 2205. https://doi.org/ $10.3390 /$ su10072205
Lam, P. L., \& Shiu, A. (2001). A data envelopment analysis of the efficiency of China's thermal power generation. Utilities Policy, 10(2), 75-83. https://doi.org/10.1016/S0957-1787(02)00036-X

Lam, P. L., \& Shiu, A. (2004). Efficiency and productivity of China's thermal power generation. Review of Industrial Organization, 24(1), 73-93. https://doi.org/10.1023/B:REIO.0000031347.79588.f3

Lin, B., \& Jiang, Z. (2011). Estimates of energy subsidies in China and impact of energy subsidy reform. Energy Economics, 33(2), 273-283. https://doi.org/10.1016/j.eneco.2010.07.005

Ma, C., \& Zhao, X. (2015). China's electricity market restructuring and technology mandates: Plant-level evidence for changing operational efficiency. Energy Economics, 47, 227-237. https://doi.org/10.1016/j. eneco.2014.11.012

Ma, H., Shi, C., \& Chou, N. T. (2016). China's water utilization efficiency: An analysis with environmental considerations. Sustainability, 8(6), 516. https://doi.org/10.3390/su8060516

Marques, R., Berg, S., \& Yane, S. (2014). Nonparametric benchmarking of Japanese water utilities: Institutional and environmental factors affecting efficiency. Journal of Water Resources Planning and Management, 140(5), 562-571. https://doi.org/10.1061/(ASCE)WR.1943-5452. 0000366

Nicolini, M., \& Tavoni, M. (2017). Are renewable energy subsidies effective? Evidence from Europe. Renewable and Sustainable Energy Reviews, 74, 412-423. https://doi.org/10.1016/j.rser.2016.12.032

Ou, P., Huang, R., \& Yao, X. (2016). Economic impacts of power shortage. Sustainability, 8(7), 687. https://doi.org/10.3390/su8070687

Phillips, M. A. (2013). Inefficiency in Japanese water utility firms: A stochastic frontier approach. Journal of Regulatory Economics, 44(2), 197-214. https://doi.org/10.1007/s11149-013-9225-8

Reichenbach, J., \& Requate, T. (2012). Subsidies for renewable energies in the presence of learning effects and market power. Resource \& Energy Economics, 34(2), 236-254. https://doi.org/10.1016/j.reseneeco. 2011.11.001

Rezitis, A. N., Tsiboukas, K., \& Tsoukalas, S. (2003). Investigation of factors influencing the technical efficiency of agricultural producers participating in farm credit programs: The case of Greece. Journal of Agricultural and Applied Economics, 35(3), 529-541. https://doi.org/10.1017/S107 4070800028261

Sarıca, K., \& Or, I. (2007). Efficiency assessment of Turkish power plants using data envelopment analysis. Energy, 32(8), 1484-1499. https:// doi.org/10.1016/j.energy.2006.10.016

Smith, S. J., van Aardenne, J., Klimont, Z., Andres, R. J., Volke, A., \& Delgado, A. S. (2011). Anthropogenic sulfur dioxide emissions: 18502005. Atmospheric Chemistry and Physics, 11, 1101-1116. https://doi. org/10.5194/acp-11-1101-2011

Sueyoshi, T., \& Goto, M. (2011). Operational synergy in the US electric utility industry under an influence of deregulation policy: A linkage to financial performance and corporate value. Energy Policy, 39(2), 699-713. https://doi.org/10.1016/j.enpol.2010.10.043

Sueyoshi, T., Goto, M., \& Ueno, T. (2010). Performance analysis of US coalfired power plants by measuring three DEA efficiencies. Energy Policy, 38(4), 1675-1688. https://doi.org/10.1016/j.enpol.2009.11.017

Wang, X., \& Lin, B. (2017). Electricity subsidy reform in China. Energy \& Environment, 28(3), 245-262. https://doi.org/10.1177/0958305X16 681681

Yang, H., \& Pollitt, M. (2009). Incorporating both undesirable outputs and uncontrollable variables into DEA: The performance of Chinese coalfired power plants. European Journal of Operational Research, 197(3), 1095-1105. https://doi.org/10.1016/j.ejor.2007.12.052 
Yang, H., \& Pollitt, M. (2010). The necessity of distinguishing weak and strong disposability among undesirable outputs in DEA: Environmental performance of Chinese coal-fired power plants. Energy Policy, 38(8), 4440-4444. https://doi.org/10.1016/j.enpol.2010.03.075

Yu, F., Guo, Y., Le-Nguyen, K., Barnes, S., \& Zhang, W. (2016). The impact of government subsidies and enterprises' R\&D investment: A panel data study from renewable energy in china. Energy Policy, 89, 106-113. https://doi.org/10.1016/j.enpol.2015.11.009

Zeng, M., Yang, Y., Wang, L., \& Sun, J. (2016). The power industry reform in China 2015: Policies, evaluations and solutions. Renewable \& Sustainable Energy Reviews, 57, 94-110. https://doi.org/10.1016/j.rser.2015.12.203

Zhang, N., \& Choi, Y. (2013). Total-factor carbon emission performance of fossil fuel power plants in China: A metafrontier non-radial Malmquist index analysis. Energy Economics, 40, 549-559. https://doi.org/10. 1016/j.eneco.2013.08.012

Zhang, N., Kong, F., Choi, Y., \& Zhou, P. (2014). The effect of size-control policy on unified energy and carbon efficiency for Chinese fossil fuel power plants. Energy Policy, 70, 193-200. https://doi.org/10.1016/j. enpol.2014.03.031

Zhao, X., \& Ma, C. (2013). Deregulation, vertical unbundling and the performance of China's large coal-fired power plants. Energy Economics, 40, 474-483. https://doi.org/10.1016/j.eneco.2013.08.003

Zhou, Y., Xing, X., Fang, K., Liang, D., \& Xu, C. (2013). Environmental efficiency analysis of power industry in China based on an entropy SBM model. Energy Policy, 57, 68-75. https://doi.org/10.1016/j. enpol.2012.09.060

How to cite this article: Li F, Xie J, Wang W. Incentivizing sustainable development: The impact of a recent policy reform on electricity production efficiency in China. Sustainable Development. 2019;27:770-780. https://doi.org/10.1002/sd.1942 